\title{
Soil carbon and physical-mechanical properties after successive applications of swine and poultry organic waste ${ }^{1}$
}

\author{
José Alcides Soares de Freitas ${ }^{2}$, Vanderlei Rodrigues da Silva ${ }^{3}$, \\ Felipe Bonini da Luz ${ }^{3}$, Douglas Rodrigo Kaiser ${ }^{4}$, Anderson Luiz Zwirtes ${ }^{5}$
}

\section{ABSTRACT}

In agricultural crops, the use of swine and poultry waste as organic fertilizers results in gains in the productivity and reduction of production costs, but it may also change the physical properties and mechanical behavior of the soil, either increasing or reducing its quality. This study aimed to investigate the influence of applying increasing doses of liquid swine manure (160 m $\mathrm{ma}^{-1}$ year-1, $320 \mathrm{~m}^{3} \mathrm{ha}^{-1}$ year ${ }^{-1}$ and $480 \mathrm{~m}^{3} \mathrm{ha}^{-1}$ year $\left.{ }^{-1}\right)$ and poultry litter $\left(6 \mathrm{Mg} \mathrm{ha}^{-1}\right.$ year $^{-1}, 12 \mathrm{Mg} \mathrm{ha}^{-1}$ year $^{-1}$ and $18 \mathrm{Mg} \mathrm{ha}^{-1}$ year $^{-1}$ ), along four years, on the physical-mechanical properties and organic carbon content of a very clayey Rhodic Eutrudox. The application of liquid swine manure and poultry litter increased the surface soil organic carbon contents. The soil density decreased, whereas the total porosity and macroporosity increased, with the addition of liquid swine manure and poultry litter. There were no significant changes in the soil susceptibility to compaction.

KEYWORDS: Organic fertilization; soil physical quality; organic matter.

\section{INTRODUCTION}

The Brazilian production of pork and poultry meat and by-products is prominent in the world scenario, and has shown a marked increase in the last decades, thus becoming economically and socially important for the country. Currently, Brazil is the second largest producer and the largest exporter of chicken meat in the world, as well as the fourth largest producer and exporter of pork,

\section{RESUMO}

Propriedades físico-mecânicas e carbono do solo após aplicações sucessivas de resíduos orgânicos de aves e suínos

A adubação orgânica das culturas agrícolas com resíduos oriundos da suinocultura e da avicultura resulta em ganhos de produtividade e redução nos custos de produção, porém, pode alterar as propriedades físicas e o comportamento mecânico do solo, aumentando ou reduzindo a sua qualidade. Objetivou-se investigar a influência da aplicação superficial de doses crescentes de dejetos líquidos de suínos $\left(160 \mathrm{~m}^{3} \mathrm{ha}^{-1} \mathrm{ano}^{-1}, 320 \mathrm{~m}^{3} \mathrm{ha}^{-1} \mathrm{ano}^{-1} \mathrm{e}\right.$ $\left.480 \mathrm{~m}^{3} \mathrm{ha}^{-1} \mathrm{ano}^{-1}\right)$ e de cama de aviário $\left(6 \mathrm{Mg} \mathrm{ha}^{-1} \mathrm{ano}^{-1}, 12 \mathrm{Mg} \mathrm{ha}^{-1}\right.$ ano $^{-1}$ e $18 \mathrm{Mg} \mathrm{ha}^{-1}$ ano $^{-1}$ ), ao longo de quatro anos, sobre as propriedades físico-mecânicas e carbono orgânico de um Latossolo Vermelho muito argiloso. As aplicações de dejeto líquido de suínos e de cama de aves aumentaram os teores superficiais de carbono orgânico do solo. A densidade do solo reduziu-se, enquanto a porosidade total e a macroporosidade aumentaram, em função das adições de dejeto líquido de suínos e de cama de aves. Não houve alterações significativas na suscetibilidade do solo à compactação.

PALAVRAS-CHAVE: Adubação orgânica; qualidade física do solo; matéria orgânica.

especially for the South region, for both activities (ABPA 2017).

The organic waste generated by the swine and poultry production chain are, respectively, liquid swine manure (consisting of feces, urine, water, feed remains, hair bristles, dusts and other materials) and poultry litter (usually consisting of wood shavings or rice husks and feathers, feed remains, animal waste and skin flakes) (Silva et al. 2011). In this regard, several studies have investigated the use of

1. Received: Apr. 12, 2018. Accepted: Jun. 18, 2018. Published: Nov. 16, 2018. DOI: 10.1590/1983-40632018v4852412.

2. Cooperativa Tritícola Regional São Luizense, São Luiz Gonzaga, RS, Brasil.E-mail/ORCID: agroalcides@gmail.com/ 0000-0001-6013-6370.

3. Universidade Federal de Santa Maria, Departamento de Ciências Agronômicas e Ambientais, Frederico Westphalen, RS, Brasil.E-mail/ORCID: vanderlei@ufsm.br/0000-0002-1636-7451, boninisolos@gmail.com/0000-0002-4427-2396.

4. Universidade Federal da Fronteira Sul, Cerro Largo, RS, Brasil.E-mail/ORCID: douglasrodrigokaiser@gmail.com/ 0000-0002-2809-1835.

5. Instituto Federal de Santa Catarina, São Miguel do Oeste, SC, Brasil. E-mail/ORCID: andersonzwirtes@gmail.com/ 0000-0002-2377-3159. 
swine manure and poultry litter in the fertilization of agricultural crops such as maize, bean, soybean and wheat (Cassol et al. 2012, Sartor et al. 2012), which have shown a great potential as fertilizers, justified by the macro and micronutrient levels found in that waste (CQFS-RS/SC 2016).

Additionally, soil physical properties (i.e., soil density, porosity and aggregation) may change with the application of swine manure and poultry litter (Andrade et al. 2016, Bosch-Serra et al. 2017, Rauber et al. 2018). However, few studies have investigated the effects of such organic waste on the soil mechanical properties (i.e., penetration resistance, preconsolidation pressure and compression ratio) and its relationship with the organic carbon content, especially for a long period of time, hence requiring a greater attention from agricultural researchers.

In view of that, this study aimed to investigate the influence of applying increasing doses of liquid swine manure and poultry litter on the physicalmechanical properties and organic carbon content of a very clayey Rhodic Eutrudox.

\section{MATERIAL AND METHODS}

The experiment was carried out at the Universidade Federal de Santa Maria, in Frederico Westphalen, Rio Grande do Sul state, Brazil, using a very clayey Rhodic Eutrudox (Latossolo Vermelho Distrófico, according to the Brazilian Soil Classification System - Embrapa 2018) with $647 \mathrm{~g} \mathrm{~kg}^{-1}$ of clay, $293 \mathrm{~g} \mathrm{~kg}^{-1}$ of silt and $60 \mathrm{~g} \mathrm{~kg}^{-1}$ of sand.

Before the experiment was installed, the soil presented the following characteristics $(0.00-0.20 \mathrm{~m}$ of depth): $\mathrm{pH}\left(\mathrm{H}_{2} \mathrm{O}\right)=4.6$ (1:1); SMP index = 5.5; clay $=630 \mathrm{~g} \mathrm{~kg}^{-1}$; organic matter $=29 \mathrm{~g} \mathrm{~kg}^{-1}$; available phosphorus $(\mathrm{P}-$-mehlich 1$)=13.0 \mathrm{mg} \mathrm{dm}^{-3}$; exchangeable potassium $=252 \mathrm{mg} \mathrm{dm}^{-3}$; calcium $=3.1 \mathrm{cmol}_{\mathrm{c}} \mathrm{dm}^{-3}$; magnesium $=1.7 \mathrm{cmol}_{\mathrm{c}} \mathrm{dm}^{-3} ; \mathrm{H}+\mathrm{Al}=5.6 \mathrm{cmol}_{\mathrm{c}} \mathrm{dm}^{-3}$; exchangeable $\mathrm{Al}=1.0 \mathrm{cmol}_{\mathrm{c}} \mathrm{dm}^{-3} ; \mathrm{CEC}=11.3 \mathrm{cmol}_{\mathrm{c}} \mathrm{dm}^{-3}$; base saturation $=50.6 \%$; and Al saturation $=14.8 \%$.

The experiment started in March 2011, with the soil preparation and planting of Tifton grass (Cynodon spp.). Six months prior to the beginning of the experiment, the area was scarified, and limestone was applied at a dose sufficient to raise the soil $\mathrm{pH}$ to 6.0 (CQFS-RS/SC 2016). After liming, the soil surface was smoothed out using a set of harrows.

The experimental design was a randomized complete block, in a 7 x 4 scheme, with seven treatments and four replications. The treatments were allocated in experimental units measuring $2.5 \mathrm{~m}$ in length and $2.0 \mathrm{~m}$ in width. The treatments used were: control: no application of liquid swine manure or poultry litter; LSM160: surface application of $160 \mathrm{~m}^{3} \mathrm{ha}^{-1}$ year ${ }^{-1}$ of liquid swine manure, divided into four mid-season applications of $40 \mathrm{~m}^{3} \mathrm{ha}^{-1}$; LSM320: surface application of $320 \mathrm{~m}^{3} \mathrm{ha}^{-1}$ year ${ }^{-1}$ of liquid swine manure, divided into four midseason applications of $80 \mathrm{~m}^{3} \mathrm{ha}^{-1}$; LSM480: surface application of $480 \mathrm{~m}^{3} \mathrm{ha}^{-1}$ year ${ }^{-1}$ of liquid swine manure, divided into four mid-season applications of $120 \mathrm{~m}^{3} \mathrm{ha}^{-1}$; PL6: surface application of $6 \mathrm{Mg} \mathrm{ha}^{-1}$ year ${ }^{-1}$ of poultry litter, divided into four mid-season applications of $1.5 \mathrm{Mg} \mathrm{ha}^{-1}$; PL12: surface application of $12 \mathrm{Mg} \mathrm{ha}^{-1}$ year $^{-1}$ of poultry litter, divided into four mid-season applications of $3.0 \mathrm{Mg} \mathrm{ha}^{-1}$; and PL18: surface application of $18 \mathrm{Mg} \mathrm{ha}^{-1}$ year $^{-1}$ of poultry litter, divided into four mid-season applications of 4.5 $\mathrm{Mg} \mathrm{ha}^{-1}$. The organic waste was applied manually on the soil surface, without incorporation.

The average chemical composition of the liquid swine manure used during the 4-year experiment was estimated by its density (CQFS-RS/SC 2016), obtaining nitrogen values of $2.21 \mathrm{~kg} \mathrm{~m}^{-3}$, phosphorus content $\left(\mathrm{P}_{2} \mathrm{O}_{5}\right)$ of $1.75 \mathrm{~kg} \mathrm{~m}^{-3}$ and potassium $\left(\mathrm{K}_{2} \mathrm{O}\right)$ content of $1.25 \mathrm{~kg} \mathrm{~m}^{-3}$. The poultry litter was obtained from an avian farm with cycles of 5 to 6 lots, with amounts added to the soil of $35 \mathrm{~kg} \mathrm{Mg}^{-1}(\mathrm{~N})$, $38 \mathrm{~kg} \mathrm{Mg}^{-1}\left(\mathrm{P}_{2} \mathrm{O}_{5}\right)$ and $30 \mathrm{~kg} \mathrm{Mg}^{-1}\left(\mathrm{~K}_{2} \mathrm{O}\right)$ of poultry bed (CQFS-RS/SC 2016).

Soil samples were collected in June 2016, when the experiment had already a four-year background with the treatments previously described. During the whole period of the experiment, Tifton grass (Cynodon spp.) was maintained in the area and was cut only when the plants reached the height of $0.3 \mathrm{~m}$. For that, a gasoline side cutter was used, and the cut material was removed from the experimental area after each cut.

Soil samples with a preserved and non-preserved structure were collected at layer depths of 0.00-0.05 m, 0.05-0.10 $\mathrm{m}$ and $0.10-0.20 \mathrm{~m}$, using, for the preservedstructure samples, four points in each layer. The preserved-structure samples were used to determine the soil density, maximum density, total porosity, macroporosity, microporosity, preconsolidation pressure and compression ratio. The nonpreservedstructure samples were used to determine the organic carbon content and particle density. 
The preserved-structure samples were collected using stainless steel cylinders measuring $0.05 \mathrm{~m}$ in diameter and $0.053 \mathrm{~m}$ in height, introduced into the soil with the aid of a cylinder extractor and a hammer. After collection and preparation in the laboratory, the soil samples were saturated by capillarity for $24 \mathrm{~h}$ and submitted to suction to a $6 \mathrm{kPa}$ height of water column, on a tension table, at which time they were weighed and submitted to the uniaxial compression test (Silva et al. 2007), using two subsamples for each replication. After these procedures, the samples were taken to an oven heated to the temperature of $105^{\circ} \mathrm{C}$, for $24 \mathrm{~h}$, for determining the dried soil mass (Embrapa 2017).

To determine the organic carbon content of the nonpreserved-structure samples, they were manually ground in a porcelain crucible, placed in digestion tubes with potassium dichromate and sulfuric acid, and then titrated with ferric ammonium sulfate (Yeomans \& Bremner 1988).

The soil density was determined by the cylinder method (Embrapa 2017) and the soil particle density, determined by the volumetric flask and alcohol method (Embrapa 2017), was $2.8 \mathrm{Mg} \mathrm{m}^{-3}$. The total porosity was determined by calculating the ratio between the soil density and particle density, while the soil microporosity was determined by the tension table method (Embrapa 2017), in which the saturated samples were tensioned at $6 \mathrm{kPa}$. The soil macroporosity was obtained by the difference between the total soil porosity and microporosity (Embrapa 2017).

The preconsolidation pressure and compression ratio were determined with a balanced moisture at $6 \mathrm{kPa}$, on a tension table, by means of a uniaxial compression test, for which an automatic consolidometer (model CNTAIHM/BR-001/07) was used (Silva et al. 2007). The sample was subjected to seven pressure levels: $25 \mathrm{kPa}, 50 \mathrm{kPa}, 100 \mathrm{kPa}$, $200 \mathrm{kPa}, 400 \mathrm{kPa}, 800 \mathrm{kPa}$ and 1,600 kPa (Silva et al. 2007), each level being applied until the sample reached $90 \%$ of its maximum deformation (Taylor 1971), moving on to the next level without load alleviation. Subsequently, in order to adjust the soil compression curve and calculate the preconsolidation pressure and compression ratio, the Excel soil compression curve supplement developed by Gubiani et al. (2017) was used. Based on the results of the uniaxial compression test, the maximum soil density was determined, considered equal to the soil density at the end of the application of the 1,600 kPa pressure level (Suzuki et al. 2013). The relative density, or degree of compaction, was determined by dividing the soil density by the maximum density (Hakansson 1990, Reichert et al. 2007).

The data were submitted to analysis of variance and, when the effect of the treatments was significant, the means were compared by the Tukey test at 0.05 of significance. The R statistical software (R Development Core Team 2014) was used for the analysis of variance, the Tukey test and the linear correlation tests.

\section{RESULTS AND DISCUSSION}

The highest organic carbon contents were observed in the surface layer $(0.00-0.05 \mathrm{~m})$ of all treatments and decreased the greater the depth (Table 1). This increase in the carbon content can be explained by the direct effects caused by the organic waste application on the surface, and by the indirect effects produced by root growth stimulation in that layer, resulting in more biomass. Arruda et al. (2010) and Agne \& Klein (2014) evaluated the effect of increasing doses of liquid swine manure in Distroferric Red Latosols of the Santa Catarina state,

Table 1. Organic carbon contents in the Red Latosol samples after four years of application of liquid swine manure (LSM) and poultry litter (PL).

\begin{tabular}{|c|c|c|c|c|c|c|c|c|c|}
\hline \multirow{2}{*}{ Layer } & Control & LSM160 & LSM320 & LSM480 & PL6 & PL12 & PL18 & \multirow{2}{*}{ Mean } & \multirow{2}{*}{$\mathrm{CV}(\%)$} \\
\hline & & - & - Total o & anic carbon & $\left.\mathrm{kg}^{-1}\right)$ & & & & \\
\hline $0.00-0.05 \mathrm{~m}$ & $19.69 b^{*}$ & $23.68 \mathrm{ab}$ & $28.42 \mathrm{a}$ & $27.82 \mathrm{a}$ & $24.95 \mathrm{ab}$ & $24.23 \mathrm{ab}$ & $24.77 \mathrm{ab}$ & 25.65 & 13.63 \\
\hline $0.05-0.10 \mathrm{~m}$ & $21.91 \mathrm{ab}$ & $21.00 \mathrm{ab}$ & $18.29 \mathrm{~b}$ & $22.16 \mathrm{ab}$ & $25.51 \mathrm{a}$ & $20.96 \mathrm{ab}$ & $21.81 \mathrm{ab}$ & 21.62 & 11.14 \\
\hline $0.10-0.20 \mathrm{~m}$ & $12.79^{\mathrm{ns}}$ & 11.72 & 10.04 & 15.07 & 12.19 & 11.39 & 12.41 & 12.14 & 24.82 \\
\hline Mean & 18.13 & 18.80 & 18.92 & 21.68 & 20.88 & 18.86 & 19.66 & - & - \\
\hline
\end{tabular}

* Means in the layer followed by different letters differ from each other by the Tukey test at 0.05 of significance. ${ }^{\text {ns }}$ Not significant. 
Brazil, and observed no increase in the organic carbon content with increased doses; however, these authors observed a greater accumulation of organic carbon in the surface layer, related to the fact that the waste was superficially applied.

The treatments with application of poultry litter did not show any increase in the organic carbon content of the soil in the surface layer. Comin et al. (2013) compared the effects of fertilization with liquid swine manure and swine deep-litter on the soil and found that the deep-litter system provided a greater carbon accumulation in the soil than the liquid swine manure did, what, according to these authors, was due to the high carbon/nitrogen ratio of the deep-litter, providing a lower decomposition rate and a greater carbon accumulation.

The control treatment showed the highest soil density values at the 0.00-0.05 m layer (Table 2), demonstrating that the application of liquid swine manure and poultry litter caused a significant reduction in such values.

The soil density reduction with the increased organic matter content is due to the characteristics of the organic matter itself, such as its low density, and to its effect on the soil, thus increasing porosity and reducing density (Braida et al. 2006, Hati et al. 2006). Several studies in the literature have also shown benefits of organic fertilizers in reducing the soil bulk density, thus improving the soil physical quality (Hati et al. 2006, Costa et al. 2009, Mellek et al. 2010). On the other hand, changes in the soil density are not often observed because of the application of different organic fertilizers at different doses (Arruda et al. 2010, Agne \& Klein 2014). Moreover, the soil type and its characteristics, the region's climate, the management system adopted, and the type and quantity of organic material applied to the soil define whether there will be changes in its physical properties (Herencia et al. 2011). Additionally, Costa et al. (2009) state that changes in the soil physical properties with the addition of organic waste are more evident in poor soils with some degree of degradation and less evident in well-structured soils with good physical quality, what justifies the response variability found by different authors.

The application of $480 \mathrm{~m}^{3} \mathrm{ha}^{-1}$ year $^{-1}$ of liquid swine manure, when compared to the control, led to a soil density reduction from $1.28 \mathrm{Mg} \mathrm{m}^{-3}$ to $1.20 \mathrm{Mg} \mathrm{m}^{-3}$ in the $0.00-0.05 \mathrm{~m}$ layer. Reinert et al. (2008) and Kaiser et al. (2009) consider, for a clayey soil, the value of $1.4 \mathrm{Mg} \mathrm{m}^{-3}$ as the critical reference value for soil density, on which the roots of the cultivated plants can face restrictions to grow and develop. In the present study, this density reference value was not reached in any of the soil layers analyzed. However, the relationship between soil density and macroporosity (Figure 1) suggests that, for the studied soil, density values above 1.27 $\mathrm{Mg} \mathrm{m}^{-3}$ reduce the volume of macropores to values below $0.10 \mathrm{~m}^{3} \mathrm{~m}^{-3}$, what hinders the diffusion of gases in the soil, thus affecting the root system development of the cultivated plants (Tormena et al. 1998, Xu et al. 1992).

The maximum density values obtained for the Latosol samples varied from $1.45 \mathrm{Mg} \mathrm{m}^{-3}$ to $1.54 \mathrm{Mg} \mathrm{m}^{-3}$ (Table 2). Factors such as clay content and soil organic matter significantly influence the maximum soil density, and it is often reported

Table 2. Soil, maximum and relative density of the Red Latosol samples after four years of application of liquid swine manure (LSM) and poultry litter (PL).

\begin{tabular}{|c|c|c|c|c|c|c|c|c|}
\hline \multirow{2}{*}{ Layer } & Control & LSM160 & LSM320 & LSM480 & PL6 & PL12 & PL18 & \multirow{2}{*}{ Mean } \\
\hline & \multicolumn{7}{|c|}{ Soil density $\left(\mathrm{Mg} \mathrm{m}^{-3}\right)$} & \\
\hline $0.00-0.05 \mathrm{~m}$ & $1.28 \mathrm{a}^{*}$ & $1.22 \mathrm{ab}$ & $1.26 \mathrm{ab}$ & $1.20 \mathrm{~b}$ & $1.26 \mathrm{ab}$ & $1.23 \mathrm{ab}$ & $1.22 \mathrm{ab}$ & 5.67 \\
\hline $0.05-0.10 \mathrm{~m}$ & $1.26^{\mathrm{ns}}$ & 1.26 & 1.26 & 1.28 & 1.23 & 1.27 & 1.29 & 5.07 \\
\hline $0.10-0.20 \mathrm{~m}$ & $1.28^{\mathrm{ns}}$ & 1.27 & 1.26 & 1.31 & 1.26 & 1.25 & 1.27 & 5.49 \\
\hline Layer & \multicolumn{7}{|c|}{ Maximum density $\left(\mathrm{Mg} \mathrm{m}^{-3}\right)$} & Mean \\
\hline $0.00-0.05 \mathrm{~m}$ & $1.52^{\mathrm{ns}}$ & 1.45 & 1.50 & 1.49 & 1.48 & 1.50 & 1.48 & 3.79 \\
\hline $0.05-0.10 \mathrm{~m}$ & $1.50 \mathrm{ab}$ & $1.50 \mathrm{ab}$ & $1.52 \mathrm{ab}$ & $1.54 \mathrm{a}$ & $1.48 \mathrm{~b}$ & $1.49 \mathrm{ab}$ & $1.54 \mathrm{a}$ & 2.23 \\
\hline $0.10-0.20 \mathrm{~m}$ & $1.50 \mathrm{ab}$ & $1.50 \mathrm{ab}$ & $1.47 \mathrm{~b}$ & $1.54 \mathrm{a}$ & $1.49 \mathrm{ab}$ & $1.50 \mathrm{ab}$ & $1.48 \mathrm{ab}$ & 2.75 \\
\hline Layer & \multicolumn{7}{|c|}{ Relative density or degree of compaction -} & Mean \\
\hline $0.00-0.05 \mathrm{~m}$ & $0.84^{\mathrm{ns}}$ & 0.84 & 0.84 & 0.81 & 0.85 & 0.82 & 0.82 & 2.89 \\
\hline $0.05-0.10 \mathrm{~m}$ & $0.84^{\mathrm{ns}}$ & 0.84 & 0.83 & 0.83 & 0.83 & 0.85 & 0.84 & 3.13 \\
\hline $0.10-0.20 \mathrm{~m}$ & $0.85^{\mathrm{ns}}$ & 0.85 & 0.86 & 0.85 & 0.85 & 0.83 & 0.86 & 3.42 \\
\hline
\end{tabular}




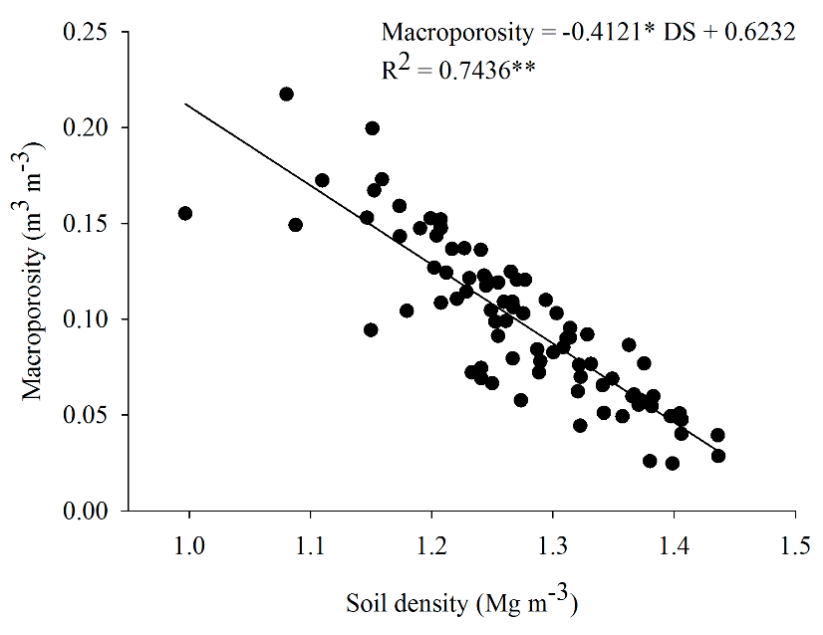

Figure 1. Relationship between the density and macroporosity of the Red Latosol samples. ** Significant at $1 \%$.

that there is an inverse relationship between these variables (Braida et al. 2006, Marcolin \& Klein 2011).

Regarding the relative density, or degree of compaction, no significant statistical differences between the treatments were observed in any of the studied layers, and the mean values showed a small variation - the lowest one was 0.81 and the highest one was 0.86 (Table 2). In a study that evaluated the influence of the application of increasing doses of liquid swine manure on the physical properties of a Latosol, Agne \& Klein (2014) observed no significant changes in the soil relative density due to the different applied doses. The relative density of 0.87 represents an optimum degree of compaction, which showed the best yields in several crops and in different soil types (Hakansson 1990). In soybean crops, Beutler et al. (2005) found an optimum relative density value equal to 0.80 , in a Red Latosol with similar characteristics to those of the soil studied here. Additionally, Reichert et al. (2009) found higher crop yields in tropical climate soils, within the relative density range of 0.80 to 0.90 . Suzuki et al. (2013) observed that, in the surface layer, an optimum degree of compaction for soybean is 0.82 for a mediumtextured Argisol (278 $\mathrm{g} \mathrm{kg}^{-1}$ of clay) and 0.85 for a clayey Oxisol (546 $\mathrm{g} \mathrm{kg}^{-1}$ of clay). Such variability in the relative density results found in the literature can be explained by the fact that the crop yield does not depend solely on the soil physical conditions, but on a number of factors such as climatic conditions, phytosanitary management and fertilization. With regard to soil compaction, Gubiani et al. (2014) demonstrated that its effects on plants depend on the availability of water during the productive cycle and may be unnoticed in years without water deficit.

The soil pore system was slightly affected by the liquid swine manure and poultry litter applications, ranging from $0.54 \mathrm{~m}^{3} \mathrm{~m}^{-3}$ in the control to $0.57 \mathrm{~m}^{3} \mathrm{~m}^{-3}$ in the treatment with a higher dose of liquid swine manure (Table 3 ).

In the 0.00-0.05 m layer, the annual application of $480 \mathrm{~m}^{3} \mathrm{ha}^{-1}$ of liquid swine manure produced a $5.5 \%$ increase in the total pore volume, if compared to the control. All treatments showed, in the most superficial layer, a tendency to increase the total pore volume, although there were no statistical differences between liquid swine manure and poultry litter. In an experiment applying different organic compounds at different doses in southwestern Iran, Barzegar et

Table 3. Total porosity, microporosity and macroporosity of the soil after four years of application of liquid swine manure (LSM) and poultry litter (PL).

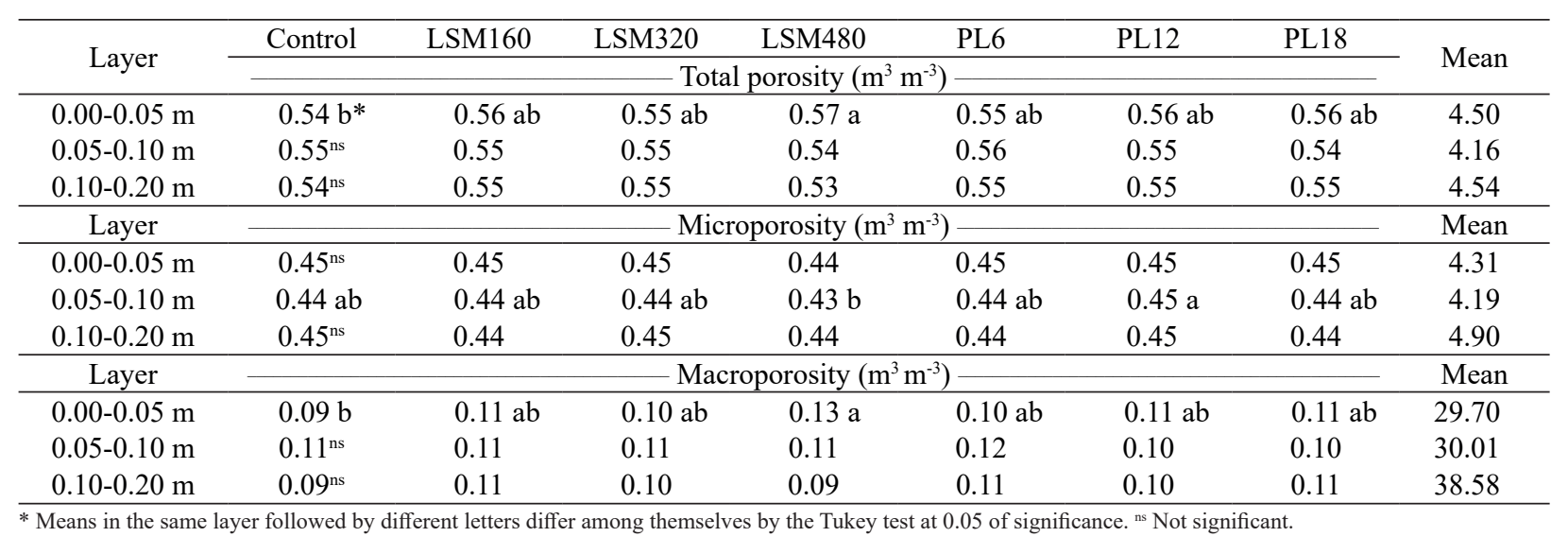


al. (2002) observed a significant increase in the total pore volume. On the other hand, Arruda et al. (2010) tested different doses of swine manure, in addition to combinations of manure with soluble fertilizers, in a Red Latosol in the Santa Catarina state, and found no changes in the soil pore system, hence attributing this result to the good quality of the soil structure prior to the beginning of the experiment. For that reason, these authors believe that the changes in the pore system with the addition of organic waste were small because the initial structural condition of the soil was good; therefore, even in the control treatment, the total pore volume was considered high and suitable for the root system development in agricultural crops.

Significant changes in the soil macroporosity were observed only at the $0.00-0.05 \mathrm{~m}$ layer, in which small increases were observed with the application of liquid swine manure and poultry litter during four years.

Regarding the preconsolidation pressure, the statistical analysis did not identify differences between the different wastes and the quantities applied, not even in the control treatment (Table 4).

The Pearson's correlation (Table 5) showed a significant positive correlation of the preconsolidation pressure with soil density and relative density, and a negative correlation with gravimetric water content, total porosity and macroporosity, showing that changes in the soil structure increase or reduce the susceptibility to compaction.

The obtained preconsolidation pressure averages varied from $69.3 \mathrm{kPa}$ to $196.5 \mathrm{kPa}$. The agricultural machines normally used in Brazilian production systems apply pressures ranging from $80 \mathrm{kPa}$ to $450 \mathrm{kPa}$ (Araujo-Junior et al. 2011, Mion et al. 2016), which can exceed $600 \mathrm{kPa}$, depending on the machine considered (Vischi Filho et al. 2015). On the other hand, animals exert pressures on the soil that vary around $350 \mathrm{kPa}$ to $400 \mathrm{kPa}$ (Betteridge et al. 1999). Therefore, it is evident that, under the studied moisture condition, the transit of machines or animals can easily exert pressures higher than the soil bearing capacity, causing an increase in compaction, thus leading to the degradation of its physical quality.

Regarding the compression ratio at the 0.00 $0.05 \mathrm{~m}$ layer, no significant statistical differences among the treatments were observed (Table 4). The variations observed for the soil compression ratio were caused by changes in the soil density and pore

Table 4. Gravimetric water content, preconsolidation pressure and compression ratio of the Red Latosol samples after four years of application of liquid swine manure (LSM) and poultry litter (PL).

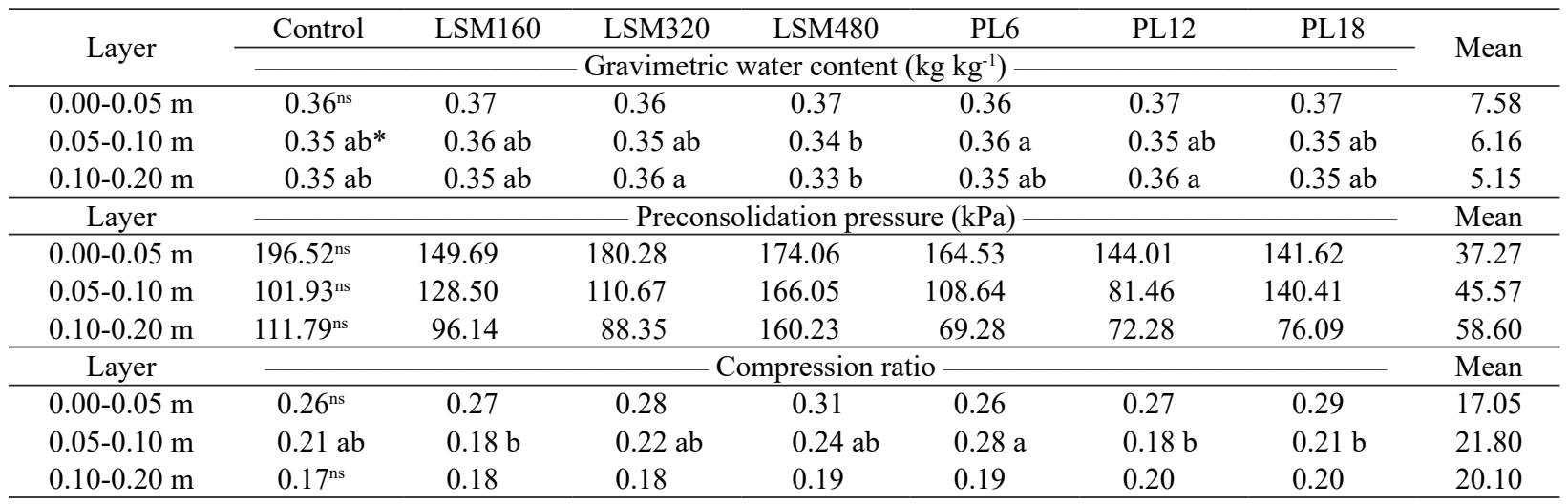

* Means in the layer followed by different letters differ from each other by the Tukey test at a 0.05 significance level. ${ }^{\text {ns }}$ Not significant.

Table 5. Pearson's correlation matrix for the preconsolidation pressure and compression ratio after four years of application of liquid swine manure and poultry litter.

\begin{tabular}{lllllllll}
\hline & GWC & SD & MD & RD & TP & MICRO & MACRO & TOC \\
\hline PCP & $-0.438^{* *}$ & $0.549^{* *}$ & $0.448^{* *}$ & $0.320^{*}$ & $-0.528^{* *}$ & $-0.062^{\text {ns }}$ & $-0.337^{*}$ & $0.261^{*}$ \\
\hline CR & $0.196^{\text {ns }}$ & $-0.486^{* *}$ & $0.06^{\text {ns }}$ & $-0.748^{* *}$ & $0.492^{* *}$ & $-0.328^{*}$ & $0.593^{* *}$ & $0.524^{*}$ \\
\hline
\end{tabular}

* Significant at $5 \%$; ** significant at $1 \%$; ${ }^{\text {ns }}$ not significant; $\mathrm{GWC}=$ gravimetric water content; $\mathrm{SD}=$ soil density; $\mathrm{MD}=$ maximum density; RD = relative density; TP = total porosity; $\mathrm{MICRO}=$ microporosity; $\mathrm{MACRO}=$ macroporosity; $\mathrm{TOC}=$ total organic carbon; $\mathrm{PCP}=$ preconsolidation pressure; $\mathrm{CR}=$ compression ratio . 
system, which were evidenced by the Pearson's correlation (Table 5). The compression ratio showed to be negatively correlated with the soil density and degree of compaction, showing that the increase in the latter variables due to soil compaction reduces its susceptibility to new compactions, as evinced by the preconsolidation pressure increase and the compression ratio reduction. Braida et al. (2010) report that the increase of the compression ratio in soils with a greater porosity is due to the smaller number of points of contact between solid particles, thus reducing the resistance to deformations generated when the soil is subjected to external pressures.

In the 0.05-0.10 m layer, significant statistical differences were observed for the compression ratio among the treatments, and the highest mean was that of the treatment with an annual application of $6 \mathrm{Mg} \mathrm{ha}^{-1}$ of poultry litter, a result that may be related to the $16.4 \%$ increase in the organic carbon content in that treatment, in comparison with the control treatment. Considering all the data produced in the present study, higher compression ratio values were correlated with higher organic carbon contents (Table 4).

Soil susceptibility to compaction, represented by the compression ratio, was lower under conditions of denser soil or higher degrees of compaction, indicating that maintaining the soil density close to the reference value may be a strategy to reduce the soil susceptibility to new compactions.

\section{CONCLUSIONS}

1. The organic fertilization procedure with increasing doses of liquid swine manure and poultry litter, carried out during four years, produced increases of up to $44.3 \%$ in the organic carbon content of the soil, and no differences were observed between the two types of organic waste studied;

2. The application of liquid swine manure or poultry litter reduced the soil density and increased the macroporosity and total porosity. Under the studied conditions, a soil density close to $1.27 \mathrm{Mg} \mathrm{m}^{-3}$ does not represent restrictive conditions for the root system of the crops and makes the soil less susceptible to compaction;

3. The preconsolidation pressure and soil susceptibility to compaction were not altered with the continuous addition of organic waste.

\section{ACKNOWLEDGMENTS}

The authors thank the Coordenação de Aperfeiçoamento de Pessoal de Nível Superior (Capes) for the master's scholarship granted to the first author, and Prof. Claudir José Basso for making available his experiment for the collection of samples.

\section{REFERENCES}

AGNE, S. A. A.; KLEIN, V. A. Matéria orgânica e atributos físicos de um Latossolo Vermelho após aplicações de dejetos de suínos. Revista Brasileira de Engenharia Agrícola e Ambiental, v. 18, n. 7, p. 720-726, 2014.

ANDRADE, A. P. et al. Changes in physical properties and organic carbon of a Kandiudox fertilized with manure. Ciência Rural, v. 46, n. 5, p. 809-814, 2016.

ARAUJO-JUNIOR, C. F. et al. Capacidade de suporte de carga e umidade crítica de um Latossolo induzida por diferentes manejos. Revista Brasileira de Ciência do Solo, v. 35, n. 1, p. 115-131, 2011.

ARRUDA, C. A. O. et al. Aplicação de dejeto suíno e estrutura de um Latossolo Vermelho sob semeadura direta. Ciência e Agrotecnologia, v. 34, n. 4, p. 804-809, 2010.

ASSOCIAÇÃO BRASILEIRA DE PROTEÍNAANIMAL (ABPA). Relatório anual. 2017. Available at: $<\mathrm{http}: / /$ abpabr.com.br/storage/files/3678c_final_abpa_relatorio_ anual_2016_portugues_web_reduzido.pdf $>$. Access on: 25 Sep. 2017.

BARZEGAR, A. R.; YOUSEFIL, A.; DARYASHENAS, A. The effect of addition of different amounts and types of organic materials on soil physical properties and yield of wheat. Plant and Soil, v. 247, n. 2, p. 295-301, 2002.

BETTERIDGE, K. et al. Effect of cattle and sheep treading on surface configuration of a sedimentary hill soil. Australian Journal of Soil Research, v. 37, n. 4, p. 743-760, 1999.

BEUTLER, A. N. et al. Densidade relativa ótima de Latossolos Vermelhos para a produtividade de soja. Revista Brasileira de Ciência do Solo, v. 29, n. 6, p. 843-849, 2005.

BOSCH-SERRA, A. D. et al. Aggregate strength in calcareous soil fertilized with pig slurries. European Journal of Soil Science, v. 68, n. 4, p. 449-461, 2017.

BRAIDA, J. A. et al. Resíduos vegetais na superfície e carbono orgânico do solo e suas relações com a densidade máxima obtida no ensaio de Proctor. Revista Brasileira de Ciência do Solo, v. 30, n. 4, p. 605-614, 2006.

BRAIDA, J. A. et al. Teor de carbono orgânico e a suscetibilidade à compactação de um Nitossolo e um 
Argissolo. Revista Brasileira de Engenharia Agrícola e Ambiental, v. 14, n. 2, p. 131-139, 2010.

CASSOL, P. C. et al. Disponibilidade de macronutrientes e rendimento de milho em Latossolo fertilizado com dejeto suíno. Revista Brasileira de Ciência do Solo, v. 36, n. 6, p. 1911-1923, 2012.

COMIN, J. J. et al. Physical properties and organic carbon content of a Typic Hapludult soil fertilized with pig slurry and pig litter in a no-tillage system. Soil Research, v. 51, n. 5, p. 459-470, 2013.

COMISSÃO DE QUÍMICA E FERTILIDADE DO SOLO (CQFS-RS/SC). Manual de calagem e adubação para os estados do Rio Grande do Sul e de Santa Catarina. Viçosa: Sociedade Brasileira de Ciência do Solo, 2016.

COSTA, A. M. et al. Potencial de recuperação física de um Latossolo Vermelho, sob pastagem degradada, influenciado pela aplicação de cama de frango. Revista Ciência e Agrotecnologia, v. 33, ed. especial, p. 19911998, 2009.

EMPRESA BRASILEIRA DE PESQUISA AGROPECUÁRIA (Embrapa). Manual de métodos de análise de solo. 3. ed. rev. e ampl. Brasília, DF: Embrapa, 2017.

EMPRESA BRASILEIRA DE PESQUISA AGROPECUÁRIA (Embrapa). Sistema brasileiro de classificação de solos. 5. ed. Brasília, DF: Embrapa, 2018.

GUBIANI, P. I. et al. Excel add-in to model the soil compression curve. Engenharia Agrícola, v. 37, n. 3, p. 603-610, 2017.

GUBIANI, P. I.; REICHERT, J. M.; REINERT, D. J. Interação entre disponibilidade de água e compactação do solo no crescimento e na produção de feijoeiro. Revista Brasileira de Ciência do Solo, v. 38, n. 3, p. 765-773, 2014.

HAKANSSON, I. A method for characterizing the state of compactness of the plough layer. Soil \& Tillage Research, v. 16, n. 1-2, p. 105-120, 1990.

HATI, K. M. et al. Effect of inorganic fertilizer and farmyard manure on soil physical properties, root distribution, and water-use efficiency of soybean in Vertisols of central India. Bioresource Technology, v. 97, n. 16, p. 2182-2188, 2006.

HERENCIA, J. F.; GARCIA-GALAVIS, P. A.; MAQUEDA, C. Long-term effect of organic and mineral fertilization on soil physical properties under greenhouse and outdoor management practices. Pedosphere, v. 21, n. 4, p. 443-453, 2011.

KAISER, D. R. et al. Intervalo hídrico ótimo no perfil explorado pelas raízes de feijoeiro em um Latossolo sob diferentes níveis de compactação. Revista Brasileira de Ciência do Solo, v. 33, n. 4, p. 845-855, 2009.

MARCOLIN, C. D.; KLEIN, V. A. Determinação da densidade relativa do solo por uma função de pedotransferência para a densidade do solo máxima. Acta Scientiarum Agronomy, v. 33, n. 2, p. 349-354, 2011.

MELLEK, J. E. et al. Dairy liquid manure and no-tillage: physical and hydraulic properties and carbon stocks in a Cambisol of southern Brazil. Soil \& Tillage Research, v. 110, n. 1, p. 69-76, 2010.

MION, R. L. et al. Tensões aplicadas no solo pelas diferentes pressões do pneu de um trator agrícola. Engenharia Agrícola, v. 36, n. 1, p. 63-77, 2016.

R DEVELOPMENT CORE TEAM. $R$ : a language and environment for statistical computing. Vienna: $\mathrm{R}$ Foundation for Statistical Computing, 2014.

RAUBER, L. P. et al. Soil physical indicators of management systems in traditional agricultural areas under manure application. Scientia Agricola, v. 75, n. 4, p. 354-359, 2018.

REICHERT, J. M. et al. Reference bulk density and critical degree-of-compactness for no-till crop production in subtropical highly weathered soils. Soil \& Tillage Research, v. 102, n. 1, p. 242-254, 2009.

REICHERT, J. M.; SUZUKI, L. E. A. S.; REINERT, D. J. Compactação do solo em sistemas agropecuários e florestais: identificação, efeitos, limites críticos e mitigação. Tópicos em Ciência do Solo, v. 5, n. 1, p. 49134, 2007.

REINERT, D. J. et al. Limites críticos de densidade do solo para o crescimento de raízes de plantas de cobertura em Argissolo Vermelho. Revista Brasileira de Ciência do Solo, v. 32, n. 5, p. 1805-1816, 2008.

SARTOR, R. L. et al. Effect of swine residue rates on corn, common bean, soybean and wheat yield. Revista Brasileira de Ciência do Solo, v. 36, n. 2, p. 661-669, 2012.

SILVA, R. B.; LANÇAS, K. P.; MASQUETTO, B. J. Consolidômetro: equipamento pneumático-eletrônico para avaliação do estado de consolidação do solo. Revista Brasileira de Ciência do Solo, v. 31, n. 4, p. 617-615, 2007.

SILVA, T. R. et al. Cultivo do milho e disponibilidade de $\mathrm{P}$ sob adubação com cama-de-frango. Revista Brasileira de Engenharia Agrícola e Ambiental, v. 15, n. 9, p. 903910, 2011.

SUZUKI, L. E. A. S.; REICHERT, J. M.; REINERT, D. J. Degree of compactness, soil physical properties and yield of soybean in six soils under no-tillage. Soil Research, v. 51, n. 4, p. 311-321, 2013. 
TAYLOR, H. M. Effects of soil strength on seedling emergence, root growth and crop yield. In: BARNES, K. K. et al. Compaction of agricultural soils. St. Joseph: ASAE, 1971. p. 292-305.

TORMENA, C. A.; SILVA, A. P.; LIBARDI, P. L. Caracterização do intervalo hídrico ótimo de um Latossolo Roxo sob plantio direto. Revista Brasileira de Ciência do Solo, v. 22, n. 4, p. 573-581, 1998.

VISCHI FILHO, O. J. et al. Capacidade de suporte de carga de Latossolo Vermelho cultivado com cana-de-açúcar e efeitos da mecanização no solo. Pesquisa Agropecuária Brasileira, v. 50, n. 4, p. 322-332, 2015.

$\mathrm{XU}, \mathrm{X}$. et al. Compaction effects on the gas diffusion coefficients in soil. Soil Science Society of America Journal, v. 56, n. 6, p. 1743-1750, 1992.

YEOMANS, J. C.; BREMNER, J. M. A rapid and precise method for routine determination of organic carbon in soil. Communications in Soil Science and Plant Analysis, v. 19, n. 13, p. 1467-1476, 1988. 